\title{
Penggunaan Metode Quantum Learning dapat Meningkatkan Minat dan Kemampuan Membaca Permulaan pada Siswa Kelas 1 SDN 2 Gebang
}

\section{Sumarno}

\author{
SDN 2 Gebang \\ sumarnobetal72@gmail.com
}

\section{Article History \\ accepted 01/02/2020}

approved 01/03/2020 published 01/04/2020

\begin{abstract}
Educating children in first grade is like carving into stone that will not be easily lost, it will even imprint forever. Education in the first grade is the foundation for the education of children in the next class. In other words, the success of education in class one is very big role for the success of children in the future. The teacher always tries to convey the subject matter so that it can be mastered by students. In fact many problems exist when the teacher presents the subject matter, but the material cannot be mastered by students. The teacher must always strive so that learning objectives can be met. Specifically for Indonesian subjects in the low class, the obstacle faced is the difficulty of the teacher teaching beginning reading. Grade 1 students who are just adapting from the kindergarten / PAUD education environment to the elementary school (SD) environment, teachers must of course have the right moment to transfer knowledge to students. The teacher must play an active role to create a good and pleasant atmosphere for learning. The teacher must be able to create pleasant conditions for the learning environment so students can be active and interested in the school, especially in the material being taught. This concerns how the teacher's techniques or methods in delivering learning material. In learning Indonesian language the ability to read basic competencies (KD): Reading aloud syllables and words with the correct pronunciation in grade 1 of SD Negeri Gebang, Nguntoronadi District, Wonogiri, the value of formative completeness is only $30 \%$. Out of 13 students, only 2 students can read and recognize letters, 9 students cannot read but know letters. And 2 students have not been able to read and do not recognize letters. While the minimum completeness criteria (KKM) set is 70 . This is evident from the low interest and student learning outcomes in Indonesian subjects. Can Improve Interest and Beginning Reading Ability in Grade 1 Students of SDN 2 Gebang
\end{abstract}

Keywords: Quantum Learning, Beginning Reading Ability, SDN 2 Gebang

\begin{abstract}
Abstrak
Mendidik anak pada kelas satu ibarat membentuk ukiran di batu yang tidak akan mudah hilang, bahkan akan membekas selamanya. Pendidikan pada kelas satu adalah peletak dasar bagi pendidikan anak di kelas selanjutnya. Dengan lain ungkapan, keberhasilan pendidikan di kelas satu ini sangat berperan besar bagi keberhasilan anak di masa selanjutnya. Guru selalu berusaha untuk menyampaikan materi pelajaran agar dapat dikuasai oleh siswa. Pada kenyataannya banyak masalah yang ada ketika guru menyampaikan materi pelajaran, namun materi tidak dapat dikuasai oleh siswa. Guru harus selalu berusaha agar tujuan pembelajaran dapat terpenuhi. Khusus pada mata pelajaran Bahasa Indonesia di kelas rendah, kendala yang dihadapi adalah kesulitan guru mengajar membaca permulaan. Siswa kelas 1 yang baru beradaptasi dari lingkungan pendidikan TK/ PAUD ke lingkungan Sekolah Dasar ( SD ), guru tentunya harus mempunyai jurus jitu untuk mentransfer ilmu ke siswa. Guru harus berperan aktif untuk menciptakan suasana yang baik dan menyenangkan untuk pembelajaran. Guru harus dapat menciptakan kondisi lingkungan belajar yang menyenangkan sehingga siswa dapat aktif dan tertarik terhadap sekolah khususnya terhadap materi yang diajarkan. Hal ini
\end{abstract}


menyangkut kepada bagaimana teknik atau metode guru dalam menyampaikan materi pembelajaran. Dalam pembelajaran bahasa Indonesia kemampuan membaca kompetensi dasar (KD): Membaca nyaring suku kata dan kata dengan lafal yang tepat di kelas 1 SD Negeri Gebang Kecamatan Nguntoronadi Kabupaten Wonogiri nilai ketuntasan formatif hanya mencapai $30 \%$. Dari 13 siswa hanya 2 siswa yang dapat membaca dan mengenal huruf, 9 siswa belum dapat membaca tetapi sudah mengenal huruf. Dan 2 siswa belum dapat membaca dan belum mengenal huruf. Sedangkan kriteria ketuntasan minimal ( KKM ) yang ditetapkan adalah 70. Ini terbukti dari rendahnya minat dan hasil belajar siswa pada mata pelajaran Bahasa Indonesia. Dapat Meningkatkan Minat dan Kemampuan Membaca Permulaan pada Siswa Kelas 1 SDN 2 Gebang

Kata kunci: Quantum Learning, Kemampuan Membaca Permulaan, SDN 2 Gebang. 


\section{PENDAHULUAN}

Hasil pengamatan di kelas I SDN 2 Gebang, terdapat beberapa permasalahan kesulitan belajar baik yang bersumber dari siswa yaitu: kurangnya minat, dan siswa yang belum dapat membaca hanya sekedar mengingat ucapan guru tanpa memperhatikan rangkaian huruf yang ada. Ketika siswa disuruh membaca secara bergantian maka sering terjadi apa yang diucapkan oleh siswa tidak sesuai dengan rangkaian huruf yang dibaca. Apa yang diucapkan kadang-kadang keliru dengan bacaan di atasnya atau di bawahnya. Kesulitan yang bersumber dari luar siswa yaitu: cara mengajar guru yang cenderung monoton, tidak variatif dan membosankan bagi siswa.

Berdasarkan hal ini, guru termotivasi untuk menyampaikan pelajaran Bahasa Indonesia dengan metode yang tidak monoton dan konvensional. Guru berusaha menggunakan metode yang variatif, yang bisa meningkatkan minat dan hasil belajar siswa khususnya di mata pelajaran Bahasa Indonesia. .

Guna mengetahui hambatan yang ditemukan untuk perbaikan pembelajaran berikutnya. Dalam melakukan perbaikan pembelajaran dilakukan penelitian tindakan kelas untuk meningkatkan hasil belajar siswa.

Berdasarkan paparan di atas dan hasil refleksi diketahui bahwa proses pembelajaran yang dilakukan guru selama ini masih berfokus pada guru, maka untuk memperbaiki proses pembelajaran membaca permulaan diterapkan metode pembelajaran inovatif yang dapat melibatkan siswa aktif belajar, baik secara mental, intelektual, fisik maupun sosial, dengan harapan hasil belajar siswa meningkat. Hal inilah yang menarik untuk diadakan penelitian dengan judul "Pengunaan Metode Quantum Learning.

\section{METODE}

Peneliti ingin mengetahui sejauh mana tingkat minat dan keterampilan siswa dalam membaca permulaan tentu saja dengan pengucapan Bahasa Indonesia yang baik dan benar. Peneliti mencoba mendapatkan jawaban yang akurat dengan menggunakan sejumlah instrumen antara lain; 1 teknik pengumpulan data Untuk memperoleh data yang akuarat pengumpulan data dilakukan dengan beberapa teknik diantaranya; Melalui dokumen yaitu mengumpulkan data minat belajar dan keterampilan membaca pada saat belum diadakan tindakan ( kondisi awal), observasi yaitu mengumpulkan data dengan mengamati motivasi membaca siswa pada setiap siklus, tes yang berupa tes lesan tentang keterampilan membaca siswa pada setiap siklus. 2 Alat Pengumpulan Data. Untuk memperoleh data diperlukan alat pengumpulan data berupa; Dokumen yang berupa catatan tentang minat belajar dan keterampilan membaca siswa pada kondisi awal, lembar observasi berupa lembar pengamatan tentang minat belajar membaca pada setiap siklus, butir soal untuk tes lisan tentang keterampilan membaca siswa pada setiap siklus. 3 Validasi data. Validasi berarti menilai apa yang seharusnya dinilai dengan menggunakan alat yang sesuai untuk mengukur kompetensi siswa.

Penelitian tindakan kelas ini menggunakan trianggulasi sumber dan trianggulasi metode. Trianggulasi sumber data berasal dari guru kelas, siswa dan teman sejawat sebagai kolaborator. Trianggulasi metode yaitu data dari pengumpulan dokumen, hasil observasi dan hasil tes tertulis. Analisis data cara pengambilan data, Pengumpulan data penelitian ini dilakukan melalui catatan observasi, dan hasil tes.

Cara menganalisa data. Catatan hasil tes atau penilaian peneliti menganalisis hasil tes, Menginterpretasikan hasil catatan. Observasi dengan cara kolaborator analisis hasil observasi, diantaranya; Kegiatan ketika siswa menerima penjelasan, Kegiatan Siswa ketika mengerjakan tugas. 


\section{HASIL DAN PEMBAHASAN}

Berdasarkan hasil penelitian tindakan kelas yang dilakukan sebanyak duasiklus dapat disimpulkan bahwa: 1. Melalui penerapan metode pembelajaran quantum learning dapat meningkatkan proses pembelajaran membaca permulaan pada siswa kelas 1 SD Negeri 2 Gebang, Kecamatan Nguntoronadi Kabupaten wonogiri. 2. Melalui penerapan metode pembelajaran quantum learning dapat meningkatkan kemampuan membaca permulaan pada siswa kelas 1 SD Negeri 2 Gebang, Kecamatan Nguntoronadi Kabupaten wonogiri.

Penelitian ini dilakukan di kelas 1 SD Negeri 2 Gebang Kecamatan Nguntoronadi Kabupaten Wonogiri Tahun Pelajaran 2019/2020. Tempat penelitian ini berlokasi di SD Negeri Gebang yang berada di lingkungan Kecamatan Nguntoronadi. SD Negeri Gebang terletak di tengah pemukiman penduduk, tepatnya di sebelah timur Waduk Gajah Mungkur. Jauh dari keramaian, jalan raya dan pasar. Staf pengajar atau gurunya cukup. Jumlah guru semuanya 11 orang yang terdiri dari 6 guru kelas, 1 guru agama Islam, 1 guru penjaskes masih berstatus wiyata bhakti, 1 tenaga perpustakaan, 1 kepala sekolah, 1 penjaga sekolah. Dengan jumlah guru yang lengkap tersebut proses belajar mengajar dapat berjalan dengan baik dan lancar, sehingga siswa yang masuk ke sekolah ini tergolong cukup. Jumlah siswa seluruhnya 82 siswa.

Semua siswa yang telah disebutkan di atas, berasal dari kalangan atau latar belakang yang berbeda. Sebagian besar siswa dari kalangan keluarga petani. Kedua orang tuanya sebagian besar hanya tamat pendidikan dasar. Sehingga perhatiannya kepada anak terhadap belajar atau pendidikan kurang, akibatnya anak mempunyai kendala atau mengalami kesulitan dalam belajar. Hal tersebut mengakibatkan masih adanya kendala dalam belajar yaitu masih ada siswa yang belum bisa membaca dengan lancar. Hal ini yang mendorong untuk dilakukan penelitian pada siswa kelas I. Karena di kelas I membaca permulaan merupakan dasar untuk membaca lanjut. Jika dasar itu tidak kuat maka untuk mempelajari mata pelajaran lain akan mengalami kesulitan. Penelitian ini merupakan penelitian tindakan kelas yaitu melalui proses atau siklus berulang, bertahap, berkelanjutan yang akan direncanakan dan dilaksanakan melalui tiga siklus.

Dari masing-masing siklus atau tahapan, materi pembelajaran selalu ditingkatkan yakni dari menggabungkan huruf menjadi suku kata dan kata sambil mengeja dan membaca, kemudian menggabungkan suku kata menjadi kata sambil membaca, tahap berikutnya adalah menggabungkan kata menjadi kalimat sederhana. Setiap tindakan atau siklus diadakan tes atau evaluasi yaitu tes membaca permulaan. Pelaksanaan tindakan kelas ini terdiri dari tiga siklus, setiap meliputi empat tahapan yakni perencanaan tindakan, pelaksanaan tindakan, observasi, dan refleksi. Sebelum pelaksanaan tindakan kelas, dilakukan tes kemampuan awal untuk mengetahui kemampuan awal siswa tentang membaca permulaan. Berdasarkan hasil tes kemampuan awal pada hari Senin tanggal 10 Agustus 2019 diketahui bahwa kemampuan membaca permulaan siswa masih rendah. Hal ini dapat terlihat dari capaian nilai tes dengan rata-rata 56,06.

Nilai kemampuan membaca permulaan siswa pada kondisi awal disajikan dalam tabel 1. Tabel 1. Nilai Kemampuan Membaca Permulaan Siswa pada Kondisi Awal

\begin{tabular}{|l|l|c|}
\hline No & \multicolumn{1}{|c|}{ Uraian Pencapaian Hasil } & Jumlah/ Nilai \\
\hline 1 & Siswa yang mendapat nilai di bawah 70 & 9 anak \\
\hline 2 & Siswa yang mendapat nilai di atas 70 & 4 anak \\
\hline 3 & Rerata & 56,06 \\
\hline 4 & Keruntasan Klasikal & $25 \%$ \\
\hline
\end{tabular}


Data ini menunjukkan bahwa pembelajaran membaca permulaan belum memenuhi batas tuntas yang ditetapkan. Dengan demikian pada kondisi awal ini. Nilai pembelajaran membaca permulaan dapat dikatakan belum mencapai tujuan yang diharapkan. Setelah diadakan tes kemampuan awal selanjutnya diadakan wawancara dengan siswa. Wawancara diadakan pada tanggal 14 Agustus 2019. Berdasarkan hasil wawancara dengan siswa diketahui bahwa proses pembelajaran masih menggunakan model pembelajaran konvensional dan banyak menggunakan metode ceramah. Selain itu dalam pembelajaran masih jarang digunakan media pembelajaran. Proses pembelajaran di dalam kelas belum mengoptimalkan peran serta siswa sehingga siswa masih pasif. Mengingat begitu pentingnya mata pelajaran bahasa Indonesia dan kurangnya prestasi belajar bahasa Indonesia maka diadakan kesepakatan dengan siswa untuk dilaksanakan pembelajaran yang dapat melibatkan keaktifan siswa, yaitu penggunaan model pembelajaran Quantum Learning . Langkah ini diambil dengan tujuan agar mampu meningkatkan proses pembelajaran di kelas yang implikasinya diharapkan dapat meningkatkan kemampuan membaca siswa dan akhirnya prestasi belajar bahasa Indonesia secara umum dapat meningkat.

Kegiatan penelitian pada siklus I dilaksanakan dua kali pertemuan, tiap pertemuan selama 90 menit. Adapun tahapan pada siklus I adalah Pada tahap ini dilakukan penyusunan rencana pelaksanaan pembelajaran bahasa Indonesia Tema 1 dengan kompetensi dasar (KD 3.3 Menguraikan lambang bunyi vokal dan konsonan dalam kata bahasa Indonesia atau bahasa daerah.

Instrumen pembelajaran terdiri dari lembar observasi siswa, lembar observasi guru, lembar penilaian dan soal tes. Perangkat lain yang perlu dipersiapkan adalah media pembelajaran yang dapat menunjang kelancaran pelaksanaan pembelajaran yaitu KIT bahasa Indonesia. Selain itu hal utama yang perlu dipersiapkan dalam penyusunan RPP

Kegiatan observasi dilakukan oleh guru dan teman sejawat selama proses pembelajaran berlangsung. Hasil observasi terhadap pelaksanaan tindakan dapat dideskripsikan bahwa masih ada siswa yang kurang memperhatikan dalam pembelajaran.

Tingkat keaktifan siswa selama mengikuti pembelajaran berdasarkan hasil observasi pada siklus I yang berkategori baik dapat disajikan sebagai berikut: 1) keaktifan siswa dalam mengikuti pelajaran sebesar $67,75 \%$, 2) keaktifan siswa dalammengajukan dan menjawab pertanyaan $55,25 \%$, 3) rasa ingin tahu dan keberanian siswa meningkat $62,5 \%$, 4) kreatif dan inisiatif siswa meningkat $56,25 \%, 5$ ) aktif mengerjakan tugas pembelajaran individu maupun kelompok 50\%. Rerata aktivitas siswa yang berkategori baik dalam pembelajaran adalah 59,75\%. Hasil distribusi Setelah dilaksanakan pembelajaran pada siklus I selanjutnya diadakan tes kemampuan membaca huruf menjadi suku kata dan kata dengan lafal yang tepat. Adapun hasil tes kemampuan membaca permulaan pada siklus 1 tertera pada tabel 1 .

Tabel 2. Nilai Tes Kemampuan Membaca Permulaan Siswa pada Siklus I

\begin{tabular}{|l|l|c|}
\hline No & Uraian Pencapaian Hasil & Jumlah / Nilai \\
\hline 1. & Siswa yang mendapat nilai di bawah 70 & 7 \\
\hline 2. & Siswa yang mendapat nilai di atas 70 & 6 \\
\hline 3. & Rerata & 66,81 \\
\hline 4. & Ketuntasan Klasikal & $43,75 \%$ \\
\hline
\end{tabular}

Berdasarkan hasil observasi di atas dapat diketahui bahwa masih ada beberapa siswa yang kurang aktif dalam kegiatan pembelajaran. Untuk menindak lanjuti pembelajaran pada siklus II perlu ditekankan kepada siswa mengenai perhatian 
siswa terhadap kegiatan pembelajaran. Kurangnya keberanian siswa mengeluarkan pendapat dalam kegiatan diskusi atau kelompok karena kegiatan masih didominasasi oleh siswa yang pandai. Oleh sebab itu pada kegiatan pembelajaran berikutnya (pada siklus II) Prosentase 43,75 perlu ditekankan kepada siswa agar siswa yang pandai memberi kesempatan kepada siswa yang kurang pandai untuk mengeluarkan pendapatnya. Pada kegiatan pelaporan hasil atau presentasi masih ada beberapa siswa kurang berani mengeluarkan pendapat sehingga untuk mengatasi hal ini guru harus selalu memberi semangat agar dapat membangkitkan keberanian siswa. Pada kegiatan pembelajaran siklus I masih ada beberapa siswa yang raguragu menggunakan alat peraga, hal ini karena siswa belum terbiasa menggunakan peraga dalam kegiatan pembelajaran. Untuk mengatasi hal ini pada siklus II, guru berusaha untuk meningkatkan keberanian siswa melalui alat peraga terutama untuk menarik perhatian digunakan kartu gambar yang berwarna.

Pembelajaran membaca permulaan pada siklus II ditekankan pada kemampuan membaca suku kata menjadi kata, hal ini merupakan kelanjutan dari siklus I. Pelaksanaannya dirancang sebagai berikut. Perencanaan penelitian tindakan kelas pada tahap ini meliputi penyusunan RPP yang akan diterapkan pada siklus II. Kompetensi dasar yang dipilih adalah Tema 1 dengan kompetensi dasar (KD 3.3 Menguraikan lambang bunyi vokal dan konsonan dalam kata bahasa Indonesia atau bahasa daerah.. Kemudian menyusun instrumen pembelajaran meliputi lembar observasi kegiatan siswa, lembar penilaian, dan soal tes. Rencana pelaksanaan pembelajaran dipilih model pembelajaran Quantum Learning dengan metode struktural dengan tehnik mencari pasangan.

Tindakan perbaikan pada siklus II yang didasarkan atas refleksi pada siklus I dilaksanakan 2 kali pertemuan tiap pertemuan selama 70 menit yaitu pada tanggal 26 Agustus 2019 dan 03 Spetember 2019.

Hasil observasi pada siklus II ini dapat dideskripsikan bahwa sebagian besar siswa sudah dapat meningkatkan aktivitas dalam mengikuti pembelajaran. Semua siswa sudah aktif dalam membentuk kelompok maupun kegiatan diskusi. Dominasi siswa yang pandai telah berkurang sehingga siswa yang kurang pandai dapat menunjukkan perannya sebagai anggota kelompok. Keberanian mengungkapkan pendapat sudah semakin meningkat. Siswa yang tadinya ragu-ragu sudah terlihat berani berbicara dan berlatih membaca. Di sudut lain guru semakin meningkatkan perhatiannya kepada setiap siswa baik kelompok maupun individu, sehingga kegiatan pembelajaran semakin lancar.

Berdasarkan hasil observasi pada siklus II, tingkat aktivitas siswa dalam mengikuti pembelajaran yang berkategori baik dapat diketahui sebagai berikut:

1) Keaktifan siswa dalam mengikuti pembelajaran sebesar $75 \%$

2) Keaktifan siswa dalam mengajukan dan menjawab pertanyaan $75 \%$

3) Rasa ingin tahu dan keberanian siswa meningkat $75 \%$

4) Kreatif dan inisiatif siswa meningkat $75 \%$

5) Aktif mengerjakan tugas individu maupun kelompok $68,75 \%$

Rerata aktivitas siswa yang berkategori baik dalam mengikuti pembelajaran adalah $72,5 \%$.

Setelah selesai pelaksanaan pembelajaran siklus II kemudian diadakan tes kemampuan membaca permulaan. Dari hasil tes diperoleh nilai yang tertera pada tabel 3.

Tabel 3. Nilai Kemampuan Membaca Permulaan Siswa pada Siklus II

\begin{tabular}{|c|l|c|}
\hline No & \multicolumn{1}{|c|}{ Uraian Pencapaian Hasil } & Jumlah / Nilai \\
\hline 1. & Siswa yang mendapat nilai di bawah 70 & 4 \\
\hline 2. & Siswa yang mendapat nilai di atas 70 & 9 \\
\hline
\end{tabular}




\begin{tabular}{|c|l|c|}
\hline 3. & Rerata & 72,50 \\
\hline 4. & Ketuntasan klasikal & $70,75 \%$ \\
\hline
\end{tabular}

Siswa sudah dapat meningkatkan aktivitas dalam mengikuti pembelajaran. Mereka sudah memahami akan pentingnya kerja sama, hal ini terbukti di dalam mereka mencari pasangan yang cocok dan mendiskusikan hasil kerja. Guru perlu meningkatkan perhatian siswa terutama di dalam kegiatan mencari pasangan maupun berdiskusi, siswa dibangkitkan semangatnya sehingga aktivitas dan semangat yang sudah terbentuk pada siklus II dapat ditingkatkan Prosentase 68,75 pada pembelajaran siklus III agar pembelajaran menjadi lebih menarik dan menyenangkan.

Pembelajaran membaca permulaan pada siklus III ditujukan pada kemampuan merangkai dan membaca nyaring kata menjadi kalimat sederhana dengan lafal yang tepat. Kegiatan perbaikan pembelajaran pada siklus III ini dilaksanakan 1 kali pertemuan selama 70 menit yang didasarkan pada hasil refleksi siklus II yaitu guru harus lebih memusatkan perhatian kepada siswa baik individu maupun kelompok, serta dapat menciptakan pembelajaran yang menarik dan menyenangkan. Seperti pada perencanaan tindakan sebelumnya yaitu kegiatan diawali dengan penyusunan rencana pelaksanaan pembelajaran dengan memilih tema 1 diriku KD 3.3 Menguraikan lambang bunyi vokal dan konsonan dalam kata bahasa Indonesia atau bahasa daerah. Pada penyusunan dipilih model pembelajaran Quantum Learning dengan metode struktural tehnik mencari pasangan, karena dengan metode ini siswa dapat lebih aktif serta tercipta pembelajaran yang menarik dan menyenangkan. Kegiatan yang lain adalah penyusunan instrumen pembelajaran seperti lembar observasi kegiatan siswa, lembar observasi kegiatan guru, lembar penilaian dan soal tes, kemudian menyiapkan media pembelajaran berupa pias-pias kata dan KIT bahasa Indonesia. Siklus ini dilaksanakan pada tanggal 09 September 2019.

Hasil observasi pada siklus III dapat dideskripsikan bahwa siswa telah aktif dalam mengikuti pembelajaran sehingga terlihat adanya peningkatan, hal ini terlihat pada kegiatan mencari pasangan dan diskusi yang dilakukan siswa berjalan baik dan efektif. Siswa berani mengutarakan pendapatnya tidak hanya didominasi oleh siswa yang pandai saja tetapi semua siswa semakin antusias dalam mengikuti kegiatan pembelajaran. Pembelajaran dapat berjalan dengan baik dan menyenangkan. Tingkat aktivitas siswa dalam mengikuti pembelajaran pada siklus III yang berkategori baik dapat diketahui dari hasil observasi sebagai berikut : 1) keaktifan siswa dalam mengikuti pembelajaran $87,5 \%$, 2) keaktifan siswa dalam mengajukan dan menjawab pertanyaan $81,25 \%$, 3) rasa ingin tahu dan keberanian siswa meningkat $87,5 \%, 4$ ) kreatif dan inisiatif siswa meningkat $87,5 \%, 5)$ aktif mengerjakan tugas individu maupun kelompok $81,25 \%$. Rerata aktivitas siswa yang berkategori baik dalam mengikuti pembelajaran adalah $85 \%$.

Setelah dilaksanakan pembelajaran pada siklus III selanjutnya diadakan tes kemampuan membaca nyaring kata menjadi kalimat sederhana dengan lafal yang tepat. Adapun hasil tes kemampuan membaca permulaan pada siklus III tertera pada tabel 4.

Tabel 4. Nilai Tes kemampuan Membaca Permulaan Siswa pada Siklus III

\begin{tabular}{|c|l|c|}
\hline No & \multicolumn{1}{|c|}{ Uraian Pencapaian Hasil } & Jumlah / Nilai \\
\hline 1. & Siswa yang mendapat nilai di bawah 70 & 2 \\
\hline 2. & Siswa yang mendapat nilai di atas 70 & 11 \\
\hline 3. & Rerata & 86,81 \\
\hline 4. & Ketuntasan klasikal & $87,5 \%$ \\
\hline
\end{tabular}

Hasil tes yang disajikan pada tabel di atas menunjukkan sejumlah 2 siswa mendapat nilai kurang dari 70 , sebanyak 11 siswa mendapat nilai 70 atau lebih. Berarti 
13 siswa telah memenuhi batas tuntas. Nilai rata-rata tes kemampuan membaca permulaan 86,81, ketuntasan secara klasikal sebesar 87,5\%. Berdasarkan hasil tersebut dapat diketahui bahwa nilai rerata maupun ketuntasan klasikal tes kemampuan membaca permulaan yang dicapai siswa telah memenuhi indikator kinerja. Siswa merasa senang dan antusias dalam mengikuti pembelajaran karena dengan model pembelajaran yang dipilih seperti kegiatan bermain. Semangat kerjasama atau kelompok semakin tertanam pada diri siswa sehingga siswa telah mengetahui akan pentingnya kegiatan bersama dalam menyelesaikan tugas yaitu dapat membawa hasil yang lebih baik. Sebagian besar siswa sudah dapat membaca huruf, suku kata, kata, dan kalimat sederhana dengan lancar serta penggunaan lafal yang benar. Siswa semakin tertarik untuk belajar membaca karena mereka menyadari bahwa Prosentase $87,5 \%$ pembelajaran membaca merupakan hal yang sangat penting. Siswa telah mengetahui bahwa untuk dapat mempelajari mata pelajaran yang lain terlebih dahulu harus mampu membaca. Untuk itu siswa selalu didorong untuk rajin belajar membaca, agar mereka mampu dan gemar membaca. individual, dari hasil tes pada siklus III siswa yang berjumlah 13 orang telah mencapai nilai lebih.

Hasil penelitian tindakan kelas tentang pembelajaran membaca permulaan yang dilakukan sebanyak tiga siklus dapat disajikan sebagai berikut :

Tabel 5 Hasil Pengamatan terhadap Aktifitas Siswa Selama Mengikuti Pembelajaran Membaca Permulaan Siklus I sampai III Siklus

\begin{tabular}{|l|l|c|c|c|}
\hline \multirow{2}{*}{ No } & \multicolumn{1}{|c|}{ Aspek Pengamatan } & \multicolumn{3}{|c|}{ Siklus } \\
\cline { 3 - 5 } & \multicolumn{1}{|c|}{$\begin{array}{c}\text { I } \\
(\%)\end{array}$} & $\begin{array}{c}\text { II } \\
(\%)\end{array}$ & $\begin{array}{c}\text { III } \\
(\%)\end{array}$ \\
\hline 1 & 1 Keaktifan siswa dalam mengikuti pelajaran & 68,74 & 75 & 87,5 \\
\hline 2 & $\begin{array}{l}\text { Keaktifan siswa dalam mengajukan dan menjawab } \\
\text { pertanyaan }\end{array}$ & 56,25 & 68,75 & 81,25 \\
\hline 3 & Rasa ingin tahu dan keberanian siswa meningkat & 62,5 & 75 & 87,5 \\
\hline 4 & Kreativitas dan inisiatif siswa meningkat & 56,25 & 75 & 87,5 \\
\hline 5. & $\begin{array}{l}\text { Aktif mengerjakan tugas pembelajaran individu } \\
\text { maupun kelompok }\end{array}$ & 50 & 68,75 & 81,25 \\
\hline 6 & Rerata & 58,75 & 72,5 & 85 \\
\hline
\end{tabular}

Hasil penelitian tindakan kelas berjudul "Penggunaan Metode quantum learning Dapat Meningkatkan Minat dan Kemampuan Membaca Permulaan Pada Siswa Kelas 1 SD Negeri 2 Gebang Tahun Pelajaran 2015/ 2016”. Yang dilakukan sebanyak tiga siklus dapat meningkatkan minat belajar dan kemampuan membaca permulaan pada siswa kelas 1.

Mengacu pada simpulan tersebut, maka diharapkan model pembelajaran tersebut dapat diterapkan di dalam pembelajaran, khususnya pembelajaran membaca permulaan dalam mata pelajaran bahasa Indonesia. Dengan metode pembelajaran quantum learning tersebut, selain dapat digunakan untuk meningkatkan kemampuan membaca permulaan siswa, juga dapat meningkatkan kualitas pembelajaran serta dapat memotivasi semangat belajar siswa dalam mengikuti pelajaran. Oleh sebab itu guru hendaknya harus kreatif dan aktif dalam menerapkan metode pembelajaran quantum learning sehingga dapat menumbuhkan rasa senang kepada siswa dalam mengikuti pembelajaran, agar siswa tidak jenuh, akhirnya kemampuan membaca permulaan siswa kelas I menjadi optimal sesuai dengan batas ketuntasan belajar baik secara individual maupun kelompok. 


\section{SIMPULAN}

Berdasarkan hasil penelitian tindakan kelas yang dilakukan sebanyak dua siklus dapat disimpulkan bahwa: 1 . Melalui penerapan metode pembelajaran quantum learning dapat meningkatkan proses pembelajaran membaca permulaan pada siswa kelas 1 SD Negeri 2 Gebang, Kecamatan Nguntoronadi Kabupaten wonogiri 2. Melalui penerapan metode pembelajaran quantum learning dapat meningkatkan kemampuan membaca permulaan pada siswa kelas 1 SD Negeri 2 Gebang, Kecamatan Nguntoronadi Kabupaten wonogiri

\section{DAFTAR PUSTAKA}

Asrori, Muhammad ( 2012) Psikologi Pelajaran. Bandung; CV Wacana Prima

El Khuluqo, Ihsana (2017) Belajar dan Pembelajaran. Yogyakarta; Pustaka Pelajar

Riyanto, Yatim (2010) Metodologi Penelitian pendidikan. Surabaya; AIS

Suyatno (2004) Teknik Pembelajaran Bahasa dan sastra. Surabaya SIC 